\title{
Development of Value-Added Chocolate with Oat and Evaluation of Its Physiological Properties
}

\author{
In-Sok Lee, Young-Eun Song, Eun-Ju Song, So-Ra Choi, Hyun-Ah Han and Ki-Kwon Lee \\ Jeollabuk-do Agricultural Research and Extension Services, Iksan-si 54591, Korea
}

\begin{abstract}
This study was performed to investigate the physicochemical properties of oat chocolate. Oat samples were roasted at various temperatures $\left(0,80,120,160\right.$ and $\left.200{ }^{\circ} \mathrm{C}\right)$ for $15 \mathrm{~min}$. Oat chocolates were made by using three natural antioxidants (green tea, lavender and cactus). The acid value, Hunter's color, $\mathrm{pH}$, total acidity and sensory evaluation of oat chocolates were determined. Results showed that the acid value of roasted oat flour significantly decreased with increasing roasting temperature. Its sensorial characteristics, such as color, taste, smell and overall preference were increased relative to a temperature rise. As for oat chocolate mixture, its acid value significantly decreased as more antioxidants were added $(p<0.05)$. The lowest acid value was recorded with chocolate lavender flour after $7 \mathrm{~d}$ at $1 \%$. Findings showed that the sensory characteristics of products containing antioxidants, such as green tea and cactus, were superior to the control treatment within $7 \mathrm{~d}$. A product including $0.5 \%$ green tea marked the best sensory score among antioxidants. Compared cost among three antioxidants, green tea was the cheapest. In the end, $0.5 \%$ green tea was selected as the optimal antioxidant to make high-quality oat chocolate. An end product by mixing green tea $(0.5 \%)$ and oat was made. With respect to Hunter's color $L$ (whiteness), $a$ (redness) and $b$ (yellowness), $L$ and $a$ levels were higher when green tea was added. However, an opposite result was expressed in $b$ level. In terms of $\mathrm{pH}$ value and total acidity, the control (without antioxidant) and product with $0.5 \%$ green tea (G-0.5) were statistically identical with each other. There was difference in acid value among specimens. The acid value of G- 0.5 was lower than that of the control up to $7 \mathrm{~d}$, resulting in lower acid value than the ready-made product (D-Co.). When sensory characteristics were assessed, G-0.5 scores were higher than other specimens, including the control and ready-made products (D-Co. and H-Co.) up to $6 \mathrm{~d}$ after the manufacturing date. As a result, the addition of $0.5 \%$ green tea increased the antioxidative effect, as well as the sensory acceptability of oat chocolate.
\end{abstract}

Key words: Oat, chocolate, antioxidants, sensory evaluation.

\section{Introduction}

Oats (Avena sativa L.) rank sixth in the world cereals production statistics, following wheat, maize, rice, barley and sorghum. They have been accepted as "top 10 super foods" by Time in the USA [1]. In Korea, oat has been cultivated since 2006 in Jeongup city in large-scale, in which its yield accounts for up to $70 \%$ of the country's total production. Oats are good source of proteins, fiber and minerals. The amount of oats used for human consumption has increased progressively; the fact is that health effects of oats benefit mainly on the total dietary fiber and $\beta$-glucan content [2]. Its bran and germ also contain

Corresponding author: In-Sok Lee, Ph.D., research field: food processing. phytochemicals, including tocopherols, tocotrienols, phenolic compounds and plant sterols that have beneficial effects on health [3]. Oats are the only cereal containing globulin or legume-like protein, avenalins, as the major $(80 \%)$ storage proteins. Globulins are characterized by water solubility, because of this property [4]. Oats are reported to be used for their antioxidants, anti-inflammatory, moisturizing and even ultraviolet protecting properties. As a grain without gluten, oat flour and bran are used as an alternative food for people suffering celiac disease. As a health food, oats have received extensive attention in recent times for its ability to lower serum cholesterol level [5]. Avenanthramides enriched extracts of oats have been shown to inhibit expression of these molecules in the endothelial cells in culture 
and other tissues by suppressing NF-kB, an important transcription factor in inflammation. In addition to their anti-inflammatory properties, oat avenanthramides have been used to suppress proliferation of vascular smooth muscle cells, a process that is known to be a major contributing factor in the development of atherosclerosis. Oats are thought to play a role in glucose and insulin response levels, as the viscosity generated by $\beta$-glucan is thought to delay glucose absorption, resulting to a lower glycemic response. The consumption of whole oat products or $\beta$-glucan enriched products for people having type 2 diabetes resulted to a lower glycemic response [6]. They are responsible for decreasing total and LDL-cholesterol, and the ratio of total to HDL-cholesterol [7]. So, these factors have made oat an appealing raw material for the development of new foods and techniques in Korea.

Chocolate is made from cocoa beans, the dried and partially fermented seeds of the cacao tree (Theobroma cacao). So, it is the most commonly craved food in the world. Initially, it was thought as a luxury item, but now it is considered to be a medicine. Cocoa contains large concentration of flavonoids, epicatechin, catechin and procyanidins. The nitrogenous compounds of cocoa include both proteins and the methyl xanthin estheobromine and caffeine. They are central nervous system stimulants, diuretics and smooth muscle relaxants. Cocoa also contains minerals, such as potassium, phosphorus, copper, iron, zinc and magnesium, which potentiate health benefits of chocolate [8].

Medicinal plants, such as green tea, lavender and cactus are of great importance to the health of individuals and communities. The medicinal value of these plants lies in some chemical substances that produce a definite physiological action on the human body, being called phytochemicals. These are non-nutritive chemicals that have protective or disease preventive property. The most important of these phytochemicals are alkaloids, flavonoids, tannins and phenolic compounds [9]. Many of these indigenous plants, such as green tea, lavender and cactus are used as spices and food plants. Current research has shown that phenolic compounds contribute to the prevention of cardiovascular diseases, cancers, osteoporosis and antioxidant character with potential health benefits $[10$ 11]. They are known to have beneficial effects on cardio vascular system $[12,13]$ and have a role in the prevention of neurodegenerative diseases and diabetes mellitus [14].

There were many reports on quality property and function of chocolates made of Sochungryoun-Tang [15], Saengmaegsan [16], isoflavone-bearing product [17], monascus barley [18], citrus [19], cherry [20], garlic [21] and bokbunja [22]. However, it was reported that there was no result concerning a study of chocolate by using oat and natural antioxidants.

Accordingly, the aim of this study was to select the optimum natural antioxidants for the production of high-quality oat chocolate and evaluate the quality property and sensory score of oat chocolate.

\section{Materials and Methods}

\subsection{Materials}

Oat cultivar, Samhan, harvested from Jeongup city in the 2015 growing season and purchased at Jeongup Oat Business Agency for Brand Prestige (JOBABP) was used in this study. It was heated at different temperatures of $0,80,120,160$ and $200{ }^{\circ} \mathrm{C}$ for $15 \mathrm{~min}$ Oat grains were ground in a hammer mill (NONSTOPL, Jeonju Food Pharmaceutical Machine, Jeonju, Korea) with an 80 mesh screen. The oat flour was stored at $4{ }^{\circ} \mathrm{C}$ before the analysis. The dark chocolate (Callebaut 57.7\%, Barry Callebaut, Lebbeke-Wieze, Belgium) was imported by Je Won International (Seoul, Korea) and white chocolate (Blanc Equilibre, Cargill chocolate product, Antwerpen, Belgium) was imported by Seon In (Asan, Korea). The fresh cream (Hopla, Cooperlat, Florence, Italy) was imported by Seon In (Asan, Korea). The green tea power (Boseong Jeda, Boseong, Korea) and 
cactus power (Naturals, Gunpo, Korea) were both harvested in 2015. Dried lavender (Yuwangtang, Shaanxi, China) harvested in 2015 was imported and grinded into fine power in a domestic gristmill (Hangukin, Seoul, Korea). The mold used (LIFE OF THE PARTY AO 12PS, Sweet Treat Supply Co., Gridley, IL, USA) was a maple leaf shape. Each mold sheet consists of 12 pieces. The two ready-made chocolates were labeled as D-Co. and H-Co., purchased from a local store. All the reagents used in the study are of analytical grade (Sigma Co., St. Louis, MO, USA).

\subsection{Production of Oat Chocolate}

A recipe for production of oat chocolate was shown in Table 1. First, dark chocolate (325 g) was melted at $55^{\circ} \mathrm{C}$, poured $3 \mathrm{~mL}$ of it into each mold and made to harden at $4{ }^{\circ} \mathrm{C}$ for $20 \mathrm{~min}$. A ganache was made by mixing white chocolate $(91.5 \mathrm{~g})$, fresh cream $(91.5 \mathrm{~g})$ and antioxidants, like green tea $(0.21 \mathrm{~g}$ and $0.42 \mathrm{~g})$, lavender $(0.21 \mathrm{~g}$ and $0.42 \mathrm{~g})$ and cactus $(0.21 \mathrm{~g}$ and $0.42 \mathrm{~g}$ ). After preparing the ganache, $2.5 \mathrm{~g}$ of it was filled into a mold made previously and waited for 15 min at $4{ }^{\circ} \mathrm{C}$. Finally, the whole surface of the ganache was covered with $2 \mathrm{~mL}$ dark chocolate and cooled it for $2 \mathrm{~h}$ at room temperature. The final oat chocolates were stored at $18{ }^{\circ} \mathrm{C}$ until it was analyzed.

\subsection{Acid Value}

The acid values of oat flour and chocolate were determined according to Korean Food Standards
Codex [23]. One gram samples were weighed in 200 $\mathrm{mL}$ Erlenmeyer flask and dissolved in $100 \mathrm{~mL}$ of ethanol: diethyl ether mixture $(1: 1, \mathrm{v} / \mathrm{v})$ for $1 \mathrm{~min}$ and titrated with 2-3 drops of $0.1 \mathrm{~N}$ potassium hydroxide solution, using $1 \%$ phenolphthalein as an indicator. Simultaneously, a blank test (ethanol: diethyl ether mixture $=1: 1, \mathrm{v} / \mathrm{v}$ ) was carried out and then acid value was calculated. Analyses were carried out in triplicate and the acid value was the $\mathrm{mg} \mathrm{KOH}$ used to neutralize $1.0 \mathrm{~g}$ of sample.

\subsection{Sensory Evaluation}

A sensory evaluation was performed by eight panelists, who were trained using the guidelines and procedure. One gram of oat flour was homogenized with $5 \mathrm{~mL}$ of distilled water for $10 \mathrm{~min}$ and served to the panels. Three oat chocolates $(2 \mathrm{~g}$ per chocolate) were served to the panels. Samples were evaluated for color, smell, flavor, and overall preference, using a five-point scale method $(1$ point $=$ extremely unsatisfactory, 5 point $=$ extremely satisfactory).

\subsection{Determination of Oat Chocolate Color}

Oat chocolate color was measured in terms of $L$ (whiteness), $a$ (redness), $b$ (yellowness) values, using a colorimeter (Minolta Chroma Meter CM-3500d, Minolta Co. Ltd., Ramcy, NJ, USA) which was calibrated with a standard plate. Each oat chocolate sample was placed in a $2 \mathrm{~cm}$ diameter Petri dish, where the surface color was measured three times and mean values were used.

Table 1 Recipes for 65 oat chocolate treatments combination.

\begin{tabular}{llllllll}
\hline \multirow{2}{*}{ Samples } & \multicolumn{7}{c}{ Oat chocolate } \\
\cline { 2 - 7 } & Oat $(\mathrm{g})$ & Dark chocolate $(\mathrm{g})$ & White chocolate $(\mathrm{g})$ & Fresh cream $(\mathrm{g})$ & Green tea $(\mathrm{g})$ & Lavender $(\mathrm{g})$ & Cactus $(\mathrm{g})$ \\
\hline $\mathrm{A}$ & 42 & 325 & 91.5 & 91.5 & 0 & 0 & 0 \\
$\mathrm{~B}$ & 42 & 325 & 91.5 & 91.5 & 0.21 & 0 & 0 \\
$\mathrm{C}$ & 42 & 325 & 91.5 & 91.5 & 0.42 & 0 & 0 \\
$\mathrm{D}$ & 42 & 325 & 91.5 & 91.5 & 0 & 0.21 & 0 \\
$\mathrm{E}$ & 42 & 325 & 91.5 & 91.5 & 0 & 0.42 & 0 \\
$\mathrm{~F}$ & 42 & 325 & 91.5 & 91.5 & 0 & 0 & 0.21 \\
$\mathrm{G}$ & 42 & 325 & 91.5 & 91.5 & 0 & 0 & 0.42 \\
\hline
\end{tabular}




\subsection{Determination of $\mathrm{pH}$ and Total Acidity}

The $\mathrm{pH}$ values of oat chocolate were determined by reading from homogenates with $1 \mathrm{~g}$ of chocolate samples and $5 \mathrm{~mL}$ of distilled water, using a digital pH meter (SevenExcellence pH, Mettler-Toledo AG, Schwerzenbach, Switzerland) equipped with an electrode calibrated with phosphate buffer at $\mathrm{pH} 4.0$ and $\mathrm{pH} 7.0$ at ambient temperature. The total acidity was determined by titration using a $0.1 \mathrm{~N} \mathrm{NaOH}$ solution at an endpoint of $\mathrm{pH}$ 8.2. The amount of titrant spent was used to compute for the citric acid content (\%).

\subsection{Statistics}

Results were analyzed for analysis of variance (ANOVA) using the statistical analysis system (v. 9.1, SAS Institute, Cary, NC, USA). Means were compared at 5\% significance level using Duncan's multiple comparison.

\section{Results and Discussion}

\subsection{Acid Value of Oat Flour}

The first aim of this study was to assess the impact of roasting process on the acid value of oat grains. The acid value of raw oat was 0.3 , however, sharply increased up to 10.9 after milling (Fig. 1). After roasting treatment, it significantly declined from 10.9 at $0{ }^{\circ} \mathrm{C}$ to 1.2 at $200{ }^{\circ} \mathrm{C}$. It is concluded that physicochemical properties of oat flour were influenced by roast processing (Fig. 1). A previous study showed that heat processing inactivated enzymes that cause rancidity, resulting in increasing storage quality of oat $[24,25]$. The acid value is the best-known indicator of fatty acid oxidation that promotes off-flavor.

\subsection{Sensory Evaluation of Oat Flour}

Fig. 2 showed the sensory evaluation of differently roasted oat flour on color, taste, smell and overall preference. Most of the panelists preferred all sensory factors of oat flour roasted at $160{ }^{\circ} \mathrm{C}$ and $220{ }^{\circ} \mathrm{C}$, which is statistically same. A burnt smell could occur during roasting process at $200{ }^{\circ} \mathrm{C}$. Another author suggested that roasting improved taste and overall preference of rice and liriope tuber because of higher amount of Maillard reaction products [26, 27]. A roasting step is therefore essential in producing high-quality processed goods. So, the recommended roasting temperature for the production of oat flour is

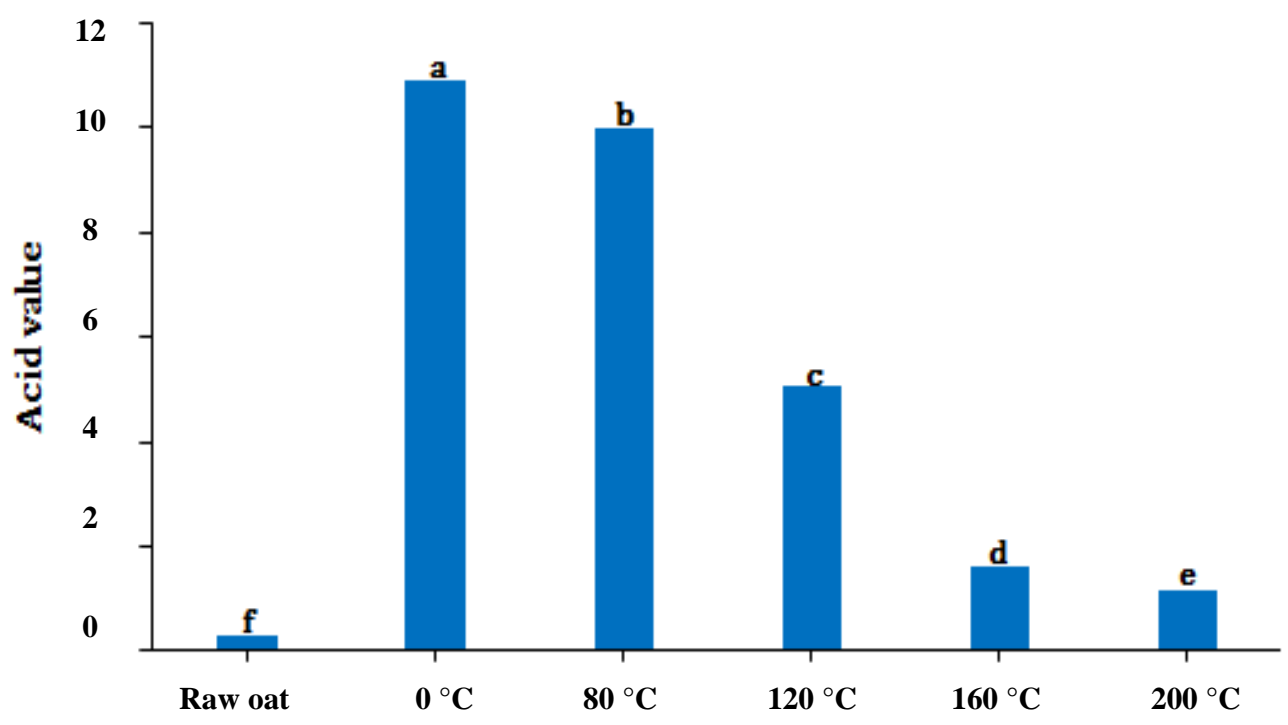

Fig. 1 Difference of acid value between raw oat and flour treated at $0,80,120,160$ and $200{ }^{\circ} \mathrm{C}$ for $15 \mathrm{~min}$.

The different letter in each treatment shows significant difference $(p<0.05)$ as determined by Duncan's multiple range test (DMRT). 


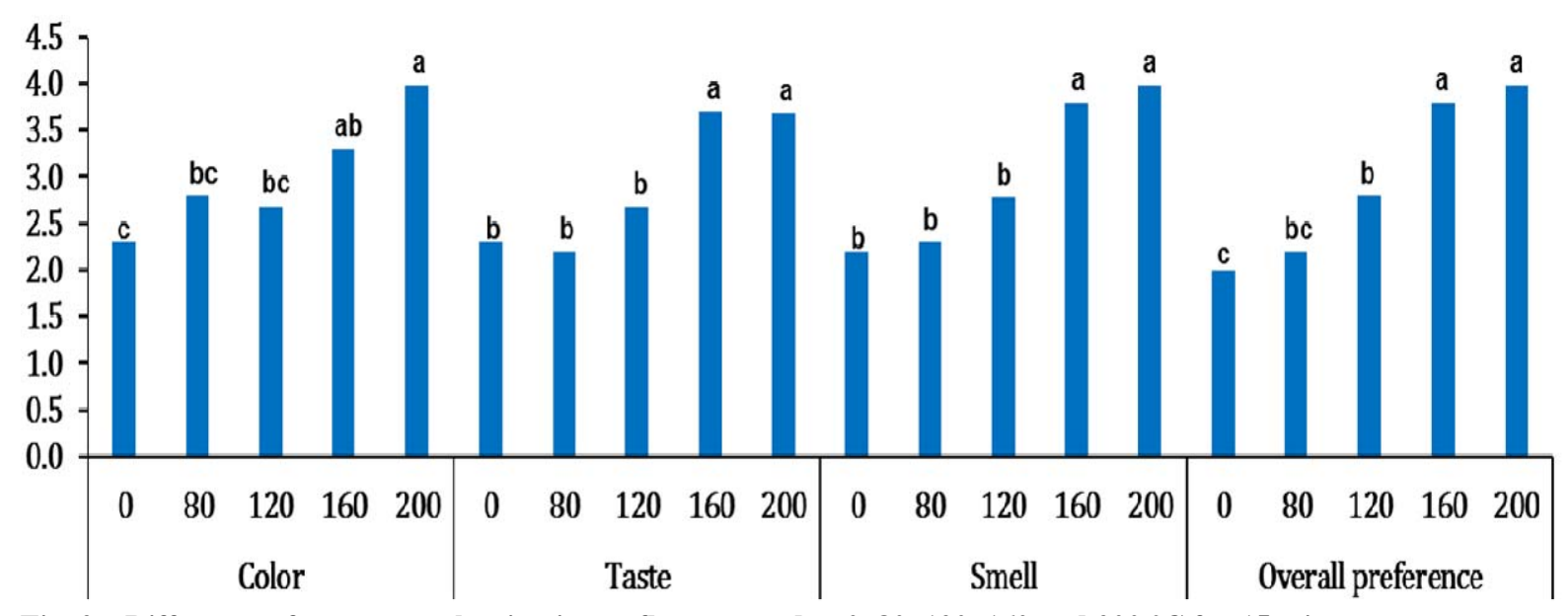

Fig. 2 Difference of sensory evaluation in oat flour treated at $0,80,120,160$ and $200{ }^{\circ} \mathrm{C}$ for $15 \mathrm{~min}$. The different letters in each sensory factor show significant difference $(p<0.05)$ as determined by DMRT.

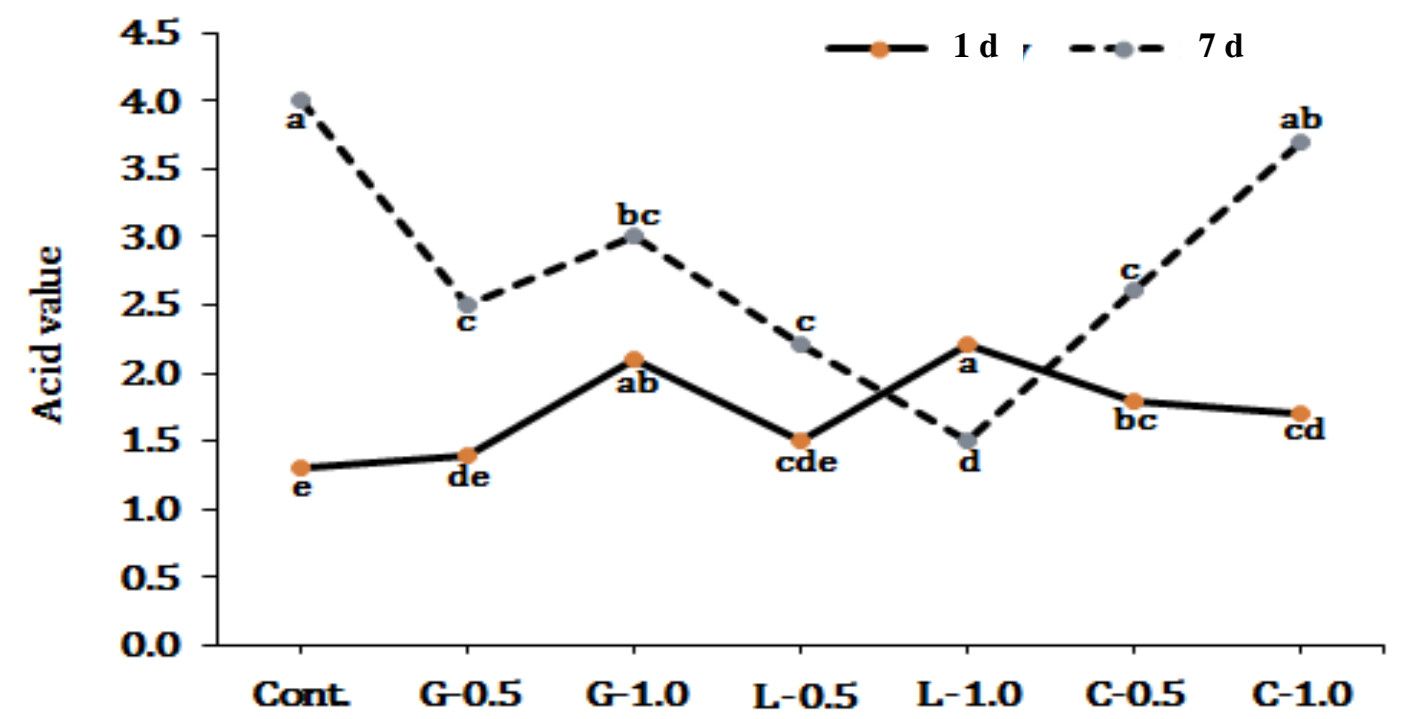

Fig. 3 Difference of acid value in oat chocolate adding green tea, lavender and cactus.

Cont.: control; G-0.5: green tea 0.5\%; G-1.0: green tea 1.0\%; L-0.5: lavender 0.5\%; L-1.0: lavender 1.0\%; C-0.5: cactus $0.5 \%$; C-1.0: cactus $1.0 \%$.

The different letters at $1 \mathrm{~d}$ and $7 \mathrm{~d}$ show significant difference $(p<0.05)$ as determined by DMRT.

$160{ }^{\circ} \mathrm{C}$ in terms of acid value and sensory evaluation. Taken together, these two factors could be used as indicators in controlling the roasting quality of oat.

\subsection{Evaluation of Three Antioxidants to Make Oat Chocolate Based on Acid Value}

The natural antioxidants have largely been viewed as tools in the fight against oxidation. This research also aims to value adding antioxidation agents, such as green tea, lavender and cactus to the oat chocolate. The acid value of oat chocolate on the actual day of manufacture was significantly higher in all the products containing antioxidants compared to the control (Fig. 3). However, by adding three antioxidants, there was a critical decrease in acid value (1.5-3.7) of the oat chocolate compared to the control (Fig. 3). This findings show that the three antioxidants can cause the decrease of acid value. A previous study also reported that the kimbugak containing green tea and cracker with a guava leaf extract were found to have a lower acid value than the control $[28,29]$. The results of this concur with their 
findings.

\subsection{Evaluation of Three Antioxidants to Make Oat Chocolate Based on Sensory}

The difference of sensory scores was examined as shown in Table 2. Its variation ranged from 2.6 to 4.0. On the day of manufacturing oat chocolate, the sensory of color, taste and overall preference showed the highest score in sample with $1.0 \%$ cactus. The smell (3.9 point) from samples with $1.0 \%$ green tea was relatively higher than that of other samples (Table 2). After $7 \mathrm{~d}$, the color, taste and overall preference of oat chocolates with $0.5 \%$ green tea scored higher than the others. But the oat chocolate with $1.0 \%$ cactus scored higher in terms of smell. In particular, when the control and oat chocolate with $0.5 \%$ green tea was compared based on sensorial quality, the latter showed a higher score than the former (Table 2). It can be inferred that there is a positive correlation between increment of sensory score and the addition of green tea. It was reported that an addition of antioxidants increased sensory evaluation, being consistent with the present result $[29,30]$.

\subsection{Comparison of Cost for Three Antioxidants to Make Oat Chocolate}

The cost is also an important factor in selecting the optimum antioxidant. Fig. 4 showed the relative cost differences among the three antioxidants. The cost of green tea was the lowest. Thus, the results suggested that the green tea was the optimum antioxidant to apply to produce oat chocolate in terms of cost.

Considering all three factors: acid value, sensory score and cost, green tea at $0.5 \%$ concentration is the recommendable additive for an optimum formulation of oat chocolate enhanced with antioxidant.

\subsection{Development of Oat Chocolate and Evaluation of Its Color, $\mathrm{pH}$ and Total Acidity}

As previously mentioned in Figs. 3 and 4, and Table 1 , the $0.5 \%$ green tea was the optimum additive for the development of the final oat chocolate. It was compared to two ready-made goods, in terms of color, $\mathrm{pH}$ and total acidity.

In terms of color, such as $L, a$ and $b$, the ready-made H-Co. in $L$ (lightness) showed the highest value as compared to the others $(p<0.05) . L$ value of oat chocolate with $0.5 \%$ green tea has lower readings than that of the control from $1 \mathrm{~d}$ to $10 \mathrm{~d}$ after manufacturing date (Table 3). A similar result was observed in previous reports $[18,29,30]$. The Hunter " $a$ " value represented redness color of the products. The " $a$ " value of the control was 4.16 on an actual day of manufacturing and its value was observably decreased as time passed by. However, the " $a$ " (redness) value variation of oat chocolate containing $0.5 \%$ green tea was small even if time went by from 1 $\mathrm{d}$ to $10 \mathrm{~d}$ (Table 2). The two ready-made goods showed high $a$ (redness) value as compared to oat chocolate containing $0.5 \%$ green tea (Table 3 ). The Hunter's $b$ value expressed yellowish-blackish color. The $b$ (yellowish) value of oat chocolate containing $0.5 \%$

Table 2 Difference of sensory score in oat chocolate containing various antioxidants in $1 \mathrm{~d}$ and $7 \mathrm{~d}$.

\begin{tabular}{|c|c|c|c|c|c|c|c|c|}
\hline \multirow{2}{*}{ Antioxidants } & \multicolumn{2}{|c|}{ Color } & \multicolumn{2}{|c|}{ Taste } & \multicolumn{2}{|c|}{ Smell } & \multicolumn{2}{|c|}{ Overall preference } \\
\hline & $1 \mathrm{~d}$ & $7 \mathrm{~d}$ & $1 \mathrm{~d}$ & $7 \mathrm{~d}$ & $1 \mathrm{~d}$ & $7 \mathrm{~d}$ & $1 \mathrm{~d}$ & $7 \mathrm{~d}$ \\
\hline Control & $3.6^{\mathrm{a}}$ & $3.3^{\mathrm{abc}}$ & $3.0^{\mathrm{ab}}$ & $3.1^{\mathrm{a}}$ & $3.4^{\mathrm{a}}$ & $3.0^{\mathrm{a}}$ & $3.1^{\mathrm{a}}$ & $3.1^{\mathrm{a}}$ \\
\hline G-0.5 & $3.4^{\mathrm{a}}$ & $3.8^{\mathrm{a}}$ & $3.4^{\mathrm{ab}}$ & $3.3^{\mathrm{a}}$ & $3.8^{\mathrm{a}}$ & $3.3^{\mathrm{a}}$ & $3.6^{\mathrm{a}}$ & $3.4^{\mathrm{a}}$ \\
\hline G-1.0 & $3.5^{\mathrm{a}}$ & $3.5^{\mathrm{ab}}$ & $3.5^{\mathrm{ab}}$ & $3.1^{\mathrm{a}}$ & $3.9^{\mathrm{a}}$ & $3.4^{\mathrm{a}}$ & $3.5^{\mathrm{a}}$ & $3.4^{\mathrm{a}}$ \\
\hline $\mathrm{L}-0.5$ & $3.5^{\mathrm{a}}$ & $2.6^{\mathrm{c}}$ & $2.8^{\mathrm{b}}$ & $3.0^{\mathrm{a}}$ & $3.4^{\mathrm{a}}$ & $3.1^{\mathrm{a}}$ & $3.1^{\mathrm{a}}$ & $2.9^{\mathrm{a}}$ \\
\hline L-1.0 & $3.5^{\mathrm{a}}$ & $2.9^{\mathrm{bc}}$ & $3.4^{\mathrm{ab}}$ & $2.8^{\mathrm{a}}$ & $3.4^{\mathrm{a}}$ & $3.0^{\mathrm{a}}$ & $3.4^{\mathrm{a}}$ & $2.8^{\mathrm{a}}$ \\
\hline C- 0.5 & $3.6^{\mathrm{a}}$ & $3.3^{\mathrm{abc}}$ & $3.6^{\mathrm{ab}}$ & $3.3^{\mathrm{a}}$ & $3.6^{\mathrm{a}}$ & $3.3^{\mathrm{a}}$ & $3.6^{\mathrm{a}}$ & $3.3^{\mathrm{a}}$ \\
\hline $\mathrm{C}-1.0$ & $4.0^{\mathrm{a}}$ & $3.5^{\mathrm{ab}}$ & $3.9^{\mathrm{a}}$ & $3.3^{\mathrm{a}}$ & $3.8^{\mathrm{a}}$ & $3.5^{\mathrm{a}}$ & $4.0^{\mathrm{a}}$ & $3.4^{\mathrm{a}}$ \\
\hline
\end{tabular}

G-0.5: green tea 0.5\%; G-1.0: green tea 1.0\%; L-0.5: lavender 0.5\%; L-1.0: lavender 1.0\%; C-0.5: cactus $0.5 \%$; C-1.0: cactus $1.0 \%$. The different letter for each column shows significant difference $(p<0.05)$ as determined by DMRT. 


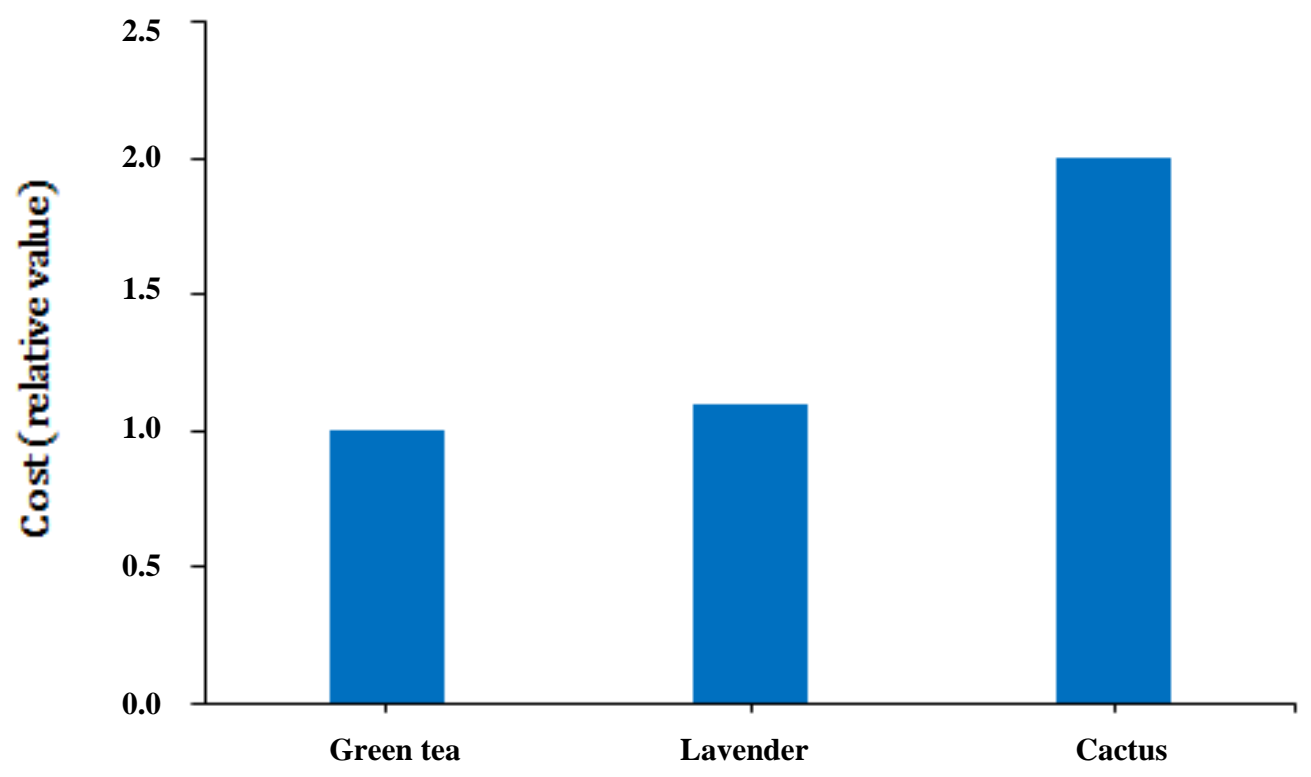

Fig. 4 Cost difference of the three antioxidants: cactus, lavender and green tea.

green tea was higher than that of the others $(p<0.05)$ (Table 3). It can be deduced that the chlorophyll in green tea has an effect on the $b$ (yellowish) color of the samples. This result was consistent with previous study in terms of $b$ value $[30,31]$.

The $\mathrm{pH}$ value ranged from 5.99 to 6.81 in all specimens from $1 \mathrm{~d}$ to $10 \mathrm{~d}$ after manufacturing. The oat chocolate's $\mathrm{pH}$ value was between the two ready-made goods (Table 3 ). There was no difference in $\mathrm{pH}$ level, even though green tea was added in oat chocolate.

With regard to total acidity, there was no statistical difference between the control and G-0.5 (green tea $0.5 \%$ ) products. The total acidity of oat chocolate showed lower range of variation than that of two ready-made goods, and was statistically lower than that of two ready-made goods (Table 3). A similar study reported that soybean curd with green tea and mulberry extract with schizandra also showed lower total acidity. Total acidity is considered a marker for food storage $[32,33]$.

\subsection{Evaluation of Acid Value in Oat Chocolate}

As previously mentioned, the acid value is an important factor to indicate fatty acid oxidation. In
Korean Food Standards Codex, an acid value of processed goods made from grain and cake \& confectionary is under 3 and 2, respectively [23]. The acid value ranged from 0.85 to 2.86 in oat chocolates during the $10 \mathrm{~d}$. The acid value was below 2 for the two ready-made goods, coded as D-Co. and H-Co., for $10 \mathrm{~d}$. Comparing the acid value of the control and G-0.5 (green tea $0.5 \%$ ), the latter was lower than the former (Fig. 5). Compared to the ready-made goods, the G-0.5's acid value was similar for the first $7 \mathrm{~d}$ with less than 2.0, being marked as box dotted line in Fig. 5. It suggested that green tea was correlated to lower acid value. Park [28] and Heo [29] reported that green tea and guava leaf extract as anti-oxidation are responsible in lowering acid value in kimbugak and cracker. The authors' results concur with their result.

\subsection{Difference of Sensory Evaluation in Oat} Chocolate

Variation in sensory characteristics, such as color, taste, smell and overall preference was observed (Table 4). The oat chocolate added with $0.5 \%$ green tea (G-0.5) showed superior color, taste, smell and overall preference to others at the first day of manufacture. Also, it represented higher taste and overall 
Table 3 Difference of Hunter's color, pH and total acidity in oat chocolate containing various antioxidants.

\begin{tabular}{|c|c|c|c|c|c|c|}
\hline \multirow{2}{*}{ Days } & \multirow{2}{*}{ Specimens } & \multicolumn{3}{|c|}{ Hunter's color } & \multirow{2}{*}{$-\mathrm{pH}$} & \multirow{2}{*}{ Total acidity } \\
\hline & & $L$ & $a$ & $b$ & & \\
\hline \multirow{4}{*}{$1 \mathrm{~d}$} & Control & $68.71^{\mathrm{b}}$ & $4.16^{\mathrm{b}}$ & $22.01^{\mathrm{b}}$ & $6.75^{\mathrm{b}}$ & $0.18^{\mathrm{c}}$ \\
\hline & G-0.5 & $66.66^{\mathrm{c}}$ & $2.65^{\mathrm{c}}$ & $23.50^{\mathrm{a}}$ & $6.79^{\mathrm{a}}$ & $0.22^{\mathrm{c}}$ \\
\hline & D-Co. & $65.95^{\mathrm{c}}$ & $7.92^{\mathrm{a}}$ & $14.80^{\mathrm{d}}$ & $6.79^{\mathrm{a}}$ & $0.37^{\mathrm{b}}$ \\
\hline & H-Co. & $76.40^{\mathrm{a}}$ & $3.92^{\mathrm{b}}$ & $19.44^{\mathrm{c}}$ & $6.28^{\mathrm{c}}$ & $0.47^{\mathrm{a}}$ \\
\hline \multirow{4}{*}{$3 \mathrm{~d}$} & Control & $65.71^{b c}$ & $1.76^{\mathrm{c}}$ & $18.38^{\mathrm{b}}$ & $6.65^{\mathrm{b}}$ & $0.21^{\mathrm{c}}$ \\
\hline & G-0.5 & $64.36^{\mathrm{c}}$ & $1.80^{\mathrm{c}}$ & $21.03^{\mathrm{a}}$ & $6.63^{\mathrm{b}}$ & $0.23^{\mathrm{c}}$ \\
\hline & D-Co. & $66.12^{\mathrm{bc}}$ & $8.08^{\mathrm{a}}$ & $15.07^{\mathrm{d}}$ & $6.76^{\mathrm{a}}$ & $0.41^{\mathrm{a}}$ \\
\hline & H-Co. & $75.19^{\mathrm{a}}$ & $3.23^{\mathrm{b}}$ & $16.63^{\mathrm{c}}$ & $6.16^{\mathrm{c}}$ & $0.35^{\mathrm{b}}$ \\
\hline \multirow{4}{*}{$6 \mathrm{~d}$} & Control & $66.34^{\mathrm{bc}}$ & $2.21^{\mathrm{c}}$ & $19.17^{\mathrm{a}}$ & $6.54^{\mathrm{b}}$ & $0.22^{\mathrm{b}}$ \\
\hline & G-0.5 & $64.90^{\mathrm{c}}$ & $2.00^{\mathrm{c}}$ & $20.96^{\mathrm{a}}$ & $6.58^{\mathrm{b}}$ & $0.24^{\mathrm{b}}$ \\
\hline & D-Co. & $67.85^{\mathrm{b}}$ & $7.77^{\mathrm{a}}$ & $14.51^{\mathrm{b}}$ & $6.72^{\mathrm{a}}$ & $0.39^{\mathrm{a}}$ \\
\hline & H-Co. & $74.14^{\mathrm{a}}$ & $3.25^{\mathrm{b}}$ & $16.11^{\mathrm{b}}$ & $6.31^{\mathrm{c}}$ & $0.40^{\mathrm{a}}$ \\
\hline \multirow{4}{*}{$8 \mathrm{~d}$} & Control & $65.94^{\mathrm{ab}}$ & $2.39^{\mathrm{c}}$ & $19.07^{\mathrm{a}}$ & $6.54^{\mathrm{b}}$ & $0.21^{\mathrm{b}}$ \\
\hline & G-0.5 & $64.61^{\mathrm{b}}$ & $2.12^{\mathrm{c}}$ & $20.76^{\mathrm{a}}$ & $6.51^{\mathrm{b}}$ & $0.22^{\mathrm{b}}$ \\
\hline & D-Co. & $65.17^{\mathrm{b}}$ & $8.39^{\mathrm{a}}$ & $15.38^{\mathrm{b}}$ & $6.74^{\mathrm{a}}$ & $0.34^{\mathrm{a}}$ \\
\hline & H-Co. & $68.06^{\mathrm{a}}$ & $4.54^{\mathrm{b}}$ & $20.35^{\mathrm{a}}$ & $5.99^{\mathrm{c}}$ & $0.33^{\mathrm{a}}$ \\
\hline \multirow{4}{*}{$10 \mathrm{~d}$} & Control & $66.18^{\mathrm{b}}$ & $2.39^{\mathrm{b}}$ & $19.15^{\mathrm{b}}$ & $6.51^{\mathrm{b}}$ & $0.23^{\mathrm{d}}$ \\
\hline & G- 0.5 & $64.21^{\mathrm{c}}$ & $1.74^{\mathrm{c}}$ & $20.48^{\mathrm{a}}$ & $6.50^{\mathrm{b}}$ & $0.24^{\mathrm{cd}}$ \\
\hline & D-Co. & $40.37^{\mathrm{d}}$ & $8.63^{\mathrm{a}}$ & $9.00^{\mathrm{d}}$ & $6.81^{\mathrm{a}}$ & $0.28^{b c}$ \\
\hline & H-Co. & $77.58^{\mathrm{a}}$ & $2.70^{\mathrm{b}}$ & $15.51^{\mathrm{c}}$ & $6.09^{c}$ & $0.46^{\mathrm{a}}$ \\
\hline
\end{tabular}

G-0.5: green tea $0.5 \%$; D-Co. and H-Co.: ready-made goods.

The different letters for each column show significant difference $(p<0.05)$ as determined by DMRT.

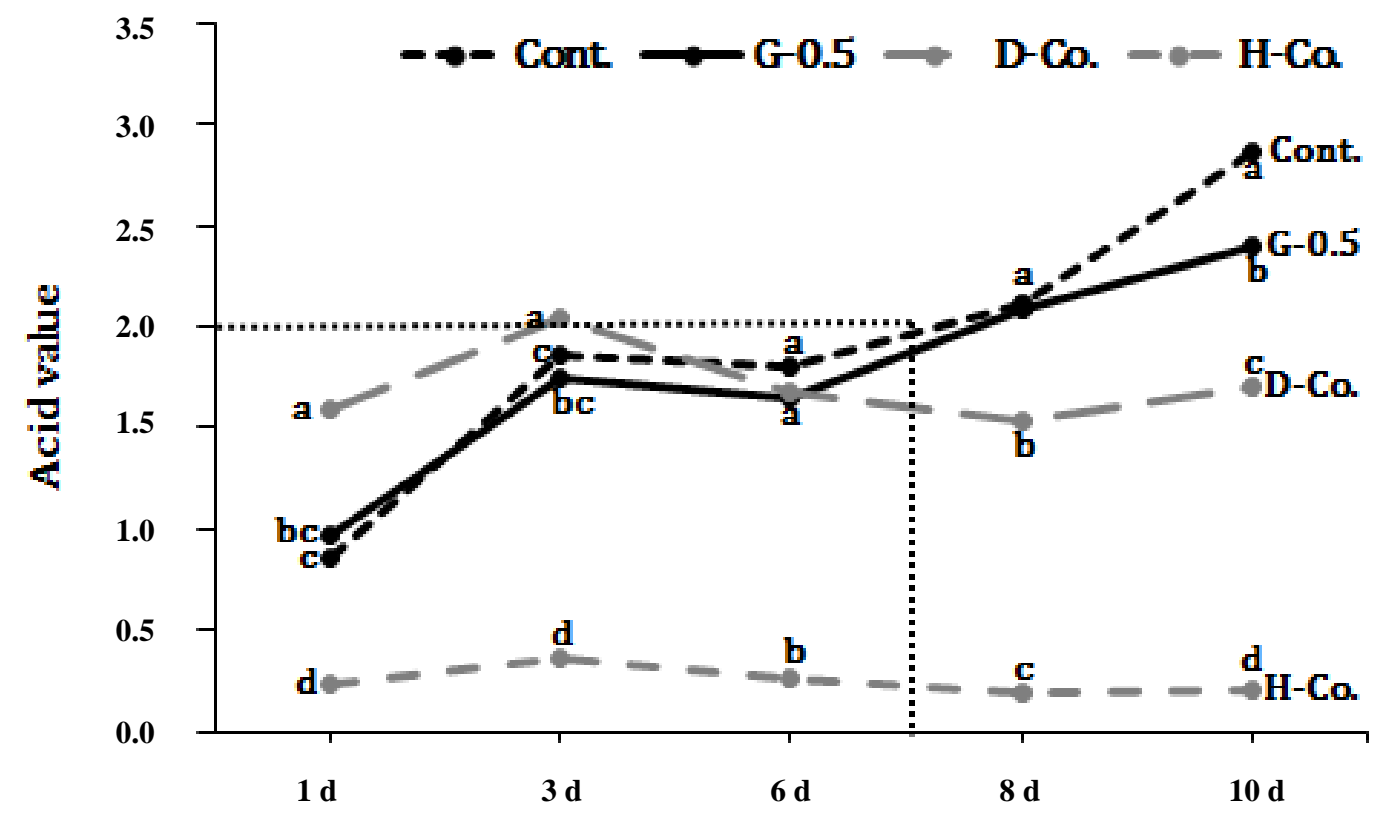

Fig. 5 Difference of acid value in chocolate products from $1 \mathrm{~d}$ to $10 \mathrm{~d}$.

Cont.: control; G-0.5: green tea $0.5 \%$; D-Co. and H-Co.: ready-made goods.

The different letters for each column show significant difference $(p<0.05)$ as determined by DMRT. 
Table 4 Difference of sensory evaluation in chocolate products from $1 \mathrm{~d}$ to $10 \mathrm{~d}$.

\begin{tabular}{|c|c|c|c|c|c|c|}
\hline Sensory & Items & $1 \mathrm{~d}$ & $3 \mathrm{~d}$ & $6 \mathrm{~d}$ & $8 \mathrm{~d}$ & $10 \mathrm{~d}$ \\
\hline \multirow{4}{*}{ Color } & Control & $3.5^{\mathrm{a}}$ & $2.9^{\mathrm{a}}$ & $2.9^{\mathrm{a}}$ & $2.8^{\mathrm{b}}$ & $2.4^{\mathrm{c}}$ \\
\hline & G-0.5 & $4.1^{\mathrm{a}}$ & $3.3^{\mathrm{a}}$ & $3.0^{\mathrm{a}}$ & $2.6^{\mathrm{b}}$ & $2.9^{\mathrm{bc}}$ \\
\hline & D-Co. & $3.5^{\mathrm{a}}$ & $3.5^{\mathrm{a}}$ & $3.3^{\mathrm{a}}$ & $3.5^{\mathrm{ab}}$ & $4.1^{\mathrm{a}}$ \\
\hline & H-Co. & $3.5^{\mathrm{a}}$ & $3.3^{\mathrm{a}}$ & $3.0^{\mathrm{a}}$ & $3.1^{\mathrm{ab}}$ & $3.5^{\mathrm{ab}}$ \\
\hline \multirow{4}{*}{ Taste } & Control & $3.8^{\mathrm{a}}$ & $3.1^{\mathrm{a}}$ & $3.4^{\mathrm{a}}$ & $2.4^{\mathrm{a}}$ & $3.0^{\mathrm{cd}}$ \\
\hline & G-0.5 & $3.9^{\mathrm{a}}$ & $3.6^{\mathrm{a}}$ & $3.3^{\mathrm{a}}$ & $2.8^{\mathrm{a}}$ & $2.8^{\mathrm{d}}$ \\
\hline & D-Co. & $3.4^{\mathrm{a}}$ & $3.6^{\mathrm{a}}$ & $3.5^{\mathrm{a}}$ & $3.3^{\mathrm{a}}$ & $4.3^{\mathrm{a}}$ \\
\hline & H-Co. & $3.5^{\mathrm{a}}$ & $3.5^{\mathrm{a}}$ & $3.8^{\mathrm{a}}$ & $3.0^{\mathrm{a}}$ & $3.5^{\mathrm{bc}}$ \\
\hline \multirow{4}{*}{ Smell } & Control & $3.6^{\mathrm{a}}$ & $3.1^{\mathrm{a}}$ & $3.3^{\mathrm{a}}$ & $3.3^{\mathrm{ab}}$ & $2.9^{\mathrm{b}}$ \\
\hline & G-0.5 & $3.6^{\mathrm{a}}$ & $3.1^{\mathrm{a}}$ & $3.1^{\mathrm{a}}$ & $2.6^{\mathrm{b}}$ & $3.0^{\mathrm{b}}$ \\
\hline & D-Co. & $3.8^{\mathrm{a}}$ & $3.4^{\mathrm{a}}$ & $3.3^{\mathrm{a}}$ & $3.5^{\mathrm{a}}$ & $4.0^{\mathrm{a}}$ \\
\hline & H-Co. & $3.6^{\mathrm{a}}$ & $3.1^{\mathrm{a}}$ & $3.5^{\mathrm{a}}$ & $3.4^{\mathrm{ab}}$ & $3.6^{\mathrm{ab}}$ \\
\hline \multirow{4}{*}{ Overall preference } & Control & $3.8^{\mathrm{a}}$ & $3.0^{\mathrm{a}}$ & $3.4^{\mathrm{a}}$ & $2.6^{\mathrm{a}}$ & $3.0^{\mathrm{b}}$ \\
\hline & G-0.5 & $3.9^{\mathrm{a}}$ & $3.8^{\mathrm{a}}$ & $3.5^{\mathrm{a}}$ & $2.8^{\mathrm{a}}$ & $2.8^{\mathrm{b}}$ \\
\hline & D-Co. & $3.5^{\mathrm{a}}$ & $3.4^{\mathrm{a}}$ & $3.1^{\mathrm{a}}$ & $3.5^{\mathrm{a}}$ & $4.4^{\mathrm{a}}$ \\
\hline & H-Co. & $3.5^{\mathrm{a}}$ & $3.4^{\mathrm{a}}$ & $3.4^{\mathrm{a}}$ & $3.0^{\mathrm{a}}$ & $3.6^{\mathrm{ab}}$ \\
\hline
\end{tabular}

G-0.5: green tea $0.5 \%$; D-Co. and H-Co.: ready-made goods.

The different letters for each column show significant difference $(p<0.05)$ as determined by DMRT.

preference than the others at $3 \mathrm{~d}$, and showed no difference at $5 \%$ level by DMRT until $6 \mathrm{~d}$ as compared to all specimens. However, all sensory characteristics in G-0.5 were significantly decreased more than that of the others after $8 \mathrm{~d}$ (Table 4). It was mentioned that adding green tea enhanced the sensory characteristics of the products $[32,34]$.

All things considered, including color, $\mathrm{pH}$, total acidity, acid value and sensory evaluation, the addition of $0.5 \%$ green tea increased the antioxidative value, as well as the sensory acceptability of oat chocolate.

\section{Conclusions}

In this study, it can be concluded that it is possible to select $160^{\circ} \mathrm{C}$ as optimum roasting temperature for a development of oat processed goods in terms of acid value and sensory evaluation. In summary, these two factors could be used as indicators in controlling the roasting quality of oat.

As for evaluation of three natural antioxidants (green tea, lavender and cactus) with acid value, sensory score and cost, green tea at $0.5 \%$ concentration is the best additive for a formulation of oat chocolate. Hence, its use could be one of the important elements for making a good oat chocolate.

The final oat chocolate containing $0.5 \%$ green tea was compared to two-ready made goods (D-Co. and H-Co.), in terms of Hunter's color value ( $L$ - lightness, $a$-redness, $b$-yellowish), $\mathrm{pH}$, total acidity, acid value and sensory evaluation. $L$ value of oat chocolate with $0.5 \%$ green tea is between D-Co. and H-Co. The two ready-made goods showed high $a$ (redness) value as compared to oat chocolate containing $0.5 \%$ green tea. The $b$ (yellowish) value of oat chocolate containing $0.5 \%$ green tea was higher than that of two-ready made goods. It can be deduced that the chlorophyll in green tea has an effect on the $b$ (yellowish) color of the oat chocolate. The oat chocolate's $\mathrm{pH}$ value (5.99-6.81) was between the two ready-made goods. There was no difference in $\mathrm{pH}$ level, even though green tea was added in oat chocolate. The total acidity of oat chocolate showed lower range of variation than that of two ready-made goods, and was statistically lower than that of two ready-made goods. From this evidence, it can be inferred that total acidity is considered a marker for food storage. The similar studies were reported from 
soybean curd and mulberry extract [32, 33]. Compared to the ready-made goods, the acid value of oat chocolate with $0.5 \%$ green tea was similar for the first $7 \mathrm{~d}$ with less than 2.0, being marked as box dotted line in Fig. 5. It suggested that green tea was correlated to lower acid value. The oat chocolate added with $0.5 \%$ green tea showed superior color, taste, smell and overall preference to two ready-made goods from the first day of manufacture to the sixth day. It was mentioned that adding a green tea enhanced the sensory characteristics of the products $[32,34]$.

All things considered including color, $\mathrm{pH}$, total acidity, acid value and sensory evaluation, the addition of $0.5 \%$ green tea increased the antioxidative value, as well as the sensory acceptability of oat chocolate.

\section{References}

[1] Horowitz, J. M. 2002. "Ten Foods that Pack a Wallop." Time 159 (3): 76-81.

[2] Ahmad, M., Zaffar, G., Dar, Z. A., and Habib, M. 2014. "A Review on Oats (Avena sativa L.) as a Dual-Purpose Crop." Scientific Research and Essays 9 (4): 52-9.

[3] Nestle. 2016. Oats for Health: A Research Summary for Health Professionals. Accessed November 1, 2016. http://www.nestle.com.au.

[4] Lásztity, R. 1996. Oat Proteins: The Chemistry of Cereal Proteins. Boca Raton, Florida: CRC Press.

[5] Schultz, W. B. 1997. "Food Labeling: Health Claims; Oats and Coronary Heart Disease." Fed. Res. 62 (15): 3584-601.

[6] Chen, J., and Raymond, K. 2008. "Beta-Glucans in the Treatment of Diabetes and Associated Cardiovascular Risks." Vasc Health and Risk Manag. 4 (6): 1265-72.

[7] Liu, S., Manson, J. E., Stampfer, M. J., Hu, F. B., Giovannucci, E., Colditz, G. A., Hennekens, C. H., and Willett, W. C. 2000. "A Prospective Study of Whole Grain Intake and Risk of Type 2 Diabetes Mellitus in US Women.” Am. J. Public Health 90 (9): 1409-15.

[8] Latif, R. 2013. "Chocolate/Cocoa and Human Health-A Review." Netherlands Journal of Medicine 71 (2): 63-8.

[9] Hill, A. F. 1952. Economic Botany: A Textbook of Useful Plants and Plant Products. New York: McGraw-Hill Book Company.

[10] Lambert, J. D., Hong, J. G., Yang, J., and Yang, C. S. 2005. "Inhibition of Carcinogenesis by Polyphenols:
Evidence from Laboratory Investigations.” Am. J. Clin. Nutr. 81: 284-91.

[11] Joseph, J. A., Shukitt-Hale, B., and Casadesus, G. 2005. "Reversing the Deleterious Effects of Aging on Neuronal Communication and Behavior: Beneficial Properties of Fruit Polyphenolic Compounds." Am. J. Clin. Nutr. 81: 313-6.

[12] Keen, C. L., Hol, R. R., Oteiza, P. I., Fraga, C. G., and Schmitz, H. H. 2005. "Cocoa Antioxidants and Cardiovascular Health.” Am. J. Clin. Nutr. 81: 298-303.

[13] Sies, H., Schewe, T., Heiss, C., and Kelm, M. 2005. "Cocoa Polyphenols and Inflammatory Mediators." Am. J. Clin. Nutr. 81: 304-12.

[14] Scalbert, A., Manach, C., Morand, C., Rémésy, C., and Jiménez, L. 2005. "Dietary Polyphenols and the Prevention of Diseases." Critical Rev. Food Sci. Nutr. 45 (4): 287-306.

[15] Yoo, K. M., Lee, K. W., Moon, B. K., and Hwang, I. K. 2005. "Antioxidant Characteristics and Preparation of Chocolate Added with Sochungryoun-Tang (Oriental Medicinal Plants Extract)." Korean J. Food Cookery Sci. 21: 585-90.

[16] Kim, W. J., Chae, H. S., Lee, Y. H., and Park, S. H. 2009. "Anti-oxidant Activity and Blood Glucose Levels according to Saengmaegsan Chocolate Intake." J. East Asian Soc. Dietary Life 19: 369-74.

[17] Moon, S. W., Park, M. S., Ahn, J. B., and Ji, G. E. 2003. "Quality Characteristics of Chocolate Blended with Bifidobacterium Fermented Isoflavone Powder." Korean J. Food Sci. Technol. 35: 1162-8.

[18] Lee, J. Y., Seo, J. S., Bang, B. H., Jeong, E. J., and Kim, K. P. 2003. "Preparation of Chocolate Added with Monascus Barley Koji Powder and Quality Characteristics." Korean J. Food \& Nutr. 16 (2): 116-22.

[19] Yoo, K. M., Lee, C. H., and Hwan, I. K. 2008. "Preparation of Chocolate Added with Yuza (Citrus junos Sieb ex TANAKA) and Its Antioxidant Characteristics." Korean J. Food Cookery Sci. 24 (2): 222-7.

[20] Yoo, M. H., Kim, K. H., Hwang, H. R., and Jo, J. E. 2009. "Quality Characteristics and Antioxidant Activity of Chocolate Containing Flowering Cherry (Prunus serrulata L. var. spontanea Max. Wils.) Fruit Powder." J. Korean Soc. Food Sci. Nutr. 38 (11): 1600-5.

[21] Shin, J. H., and Joo, N. M. 2010. "Processing Optimization of Chocolate with Fermented and Aged Garlic Extract.” Korean J. Food Culture 25: 216-24.

[22] Yu, O. K., Kim, M. A., Rho, J. O., Sohn, H. S., and Cha, Y. S. 2007. "Quality Characteristics and the Optimization Recipes of Chocolate Added with Bokbunja (Rubus coreanus Miquel).” J. Korean Soc. Food Sci. Nutr. 36 (9): 1193-7.

[23] Korea Food and Drug Administration. 2016. Korea Food 
Code, 2016: No. 5 Standards and Specifications of Each Food. Korea Food and Drug Administration, Korea, 467.

[24] Decker, E. A., Rose, D. L., and Stewart, D. 2014. "Processing of Oats and the Impact of Processing Operations on Nutrition and Health Benefits." British Journal of Nutrition 112: S58-64.

[25] Lehtinen, P., Kiiliäinen, K., Lehtomäki, I., and Laakso, S. 2003. "Effect of Heat Treatment on Lipid Stability in Processed Oats." Journal of Cereal Science 37 (2): 215-21.

[26] Lee, S. H., Lee ,Y. R., Hwang, I. G., Woo, K. S., Kim, K. H., Kim, K. J., and Jeong, S. H. 2009. "Antioxidant Activities and Quality Characteristics of Germinated Rough Rice Tea according to Roasting Temperature, Time and Leaching Condition." Korean J. Food Sci. Technol. 41 (4): 386-91.

[27] Bae, K. M., Park, S. H., Jung, K. H., Kim, M. J., Hong, S. H., Song, Y. O., and Lee, H. S. 2010. "Effects of Roasting Conditions on Physicochemical Properties and Sensory Properties of Liriopis Tuber." J. Korean Soc. Food Sci. Nutr. 39 (10): 1503-8.

[28] Park, B. H., Choi, H. K., and Cho, H. S. 2001. "A Study on the Oxidative Stability and Quality Characteristics of Kimbugak Made of Aqueous Green Tea." J. Korean Soc. Food Sci. Nutr. 30 (3): 557-64.
[29] Heo, Y. J., Sim, K. H., Choi, H. Y., and Kim, S. I. 2010. "Antioxidative Activity of Crackers Made with a Guava (Psidium guajava L.) Leaf Extract Harvested in Korea." Korean J. Food Cookery Sci. 26 (2): 171-9.

[30] Bang, B. H., Jeong, E. J., and Kim, K. P. 2012. "Quality Characteristics of Cookies Added with Guava (Psidium guajava L.) Leaf Powder.” Korean J. Food \& Nutr. 25 (2): 317-23.

[31] Yoo, K. M. 2014. "Development of Value-Added Chocolate with Korean Red Peppers (Capsicum annum L.) and Evaluation of Their Physiological Properties." Korean J. Food \& Nutr. 27 (4): 678-83.

[32] Choi, Y. C., Chung, H. S., and Youn, K. S. 2000. "Effects of Various Concentrations of Natural Materials on the Manufacturing of Soybean Curd." Korean J. Postharvest Sci. Technol. 7 (3): 256-61.

[33] Im, H. E., Kim, Y. W., Jeong, S. T., Yeo, S. H., Baek, S. Y., Kim, J. H., Oh., S. G., and Park, H. Y. 2015. "Effect of Omija (Schisandra chinensis Baillon) Addition Ratio on Quality Characteristics of Mulberry Extracts." $J$. Korean Soc. Food Sci. Nutr. 44 (7): 1041-9.

[34] Han, H. M., Woo, K. S., Lee, B. W., Park, J. Y., Sim, E. Y., Kim, B. J., Lee, C. W., Kim, S. J., Kim, W. H., Lee, J. S., and Lee, Y. Y. 2015. "Antioxidant Compounds and Activities of Methanolic Extracts from Oat Cultivars." J. Korean Soc. Food Sci. Nutr. 44 (11): 1660-5. 